\title{
Comparison of sense of efficacy for pre-service and in-service teachers
}

\author{
Şenol Şen ${ }^{1, *}$ \\ ${ }^{1}$ Hacettepe University, Department of Mathematics and Science Education, 06800, Beytepe, Ankara, \\ Turkey
}

\begin{abstract}
The aim of this study was to compare the sense of efficacy for pre-service and in-service teachers. The study was conducted with 64 preservice (32 chemistry and 32 mathematics) and 64 in-service teachers (32 chemistry and 32 mathematics). The short version of the Teachers' Sense of Efficacy Scale (TSES) was used as a data collection tool. The scale was consisted of 12-items divided into three sub-scales, named as Efficacy for instructional Strategies, Efficacy for Classroom Management, and Efficacy for Student Engagement. An independent-samples t-test was used to compare the sense of efficacy scores for pre-service and in-service teachers. According to independent samples t-test analysis, there was only a statistically significant difference in Efficacy for Classroom Management scores for pre-service $(\mathrm{M}=25.64, \mathrm{SD}=5.4)$ and in-service teachers $(\mathrm{M}=$ $28.06, \mathrm{SD}=2.17 ; \mathrm{t}(126)=-3.329, \mathrm{p}=.001$, two-tailed). However, there was no significant difference in Efficacy for Instructional Strategies and Efficacy for Student Engagement scores for pre-service and in-service teachers.
\end{abstract}

\section{Introduction}

Self-efficacy is an individual's self-judgement that he/she can arrange the activities necessary for fulfilling a certain task and thus can achieve success [1]. It is an individual's belief about the extent to which he/she can cope with challenges that he/she might encounter in the future [2]. Individuals who think that they have competence to fulfil a task and self-confidence in their abilities could achieve more success [1,3]. Teachers' selfefficacy is the most important belief influencing their professional behaviors [4]. Besides, their self-efficacy beliefs are associated with their behaviors in the classroom. Efficacy influences the degree of teachers' efforts they make in learning-teaching process and the degree of their goals and demands [2]. Based on social cognitive theory, teacher selfefficacy can be described as teachers' individual beliefs in their abilities related to perform, organize and plan the activities for educational goals [5]. Teachers having high self-efficacy also have high levels of planning and organizing [6], they are open to new ideas and they are more willing to try new methods to enable their students to understand better $[2,7]$. Teachers having low self-efficacy, however, encounter problems in teaching, they are less pleased with their job and they suffer from job-related stress more [5]. Besides, teachers' self-efficacy is associated with their in-class behaviors; and it is also influential in students'

\footnotetext{
* Corresponding author: schenolschen@gmail.com
} 
achievement, motivation and self-efficacy [2]. Therefore, teacher's self-efficacy beliefs have an important role on the behavior of both in-service and pre-service teachers in their learning-teaching environment. From this point, self-efficacy beliefs need to be examined for in-service and pre-service teachers as a key factor in education.

\subsection{The aim of the study}

The aim of this study was to compare the sense of efficacy for pre-service and in-service chemistry and mathematics teachers.

\section{Method}

\subsection{Study group}

The study was conducted with a total of 64 pre-service (32 chemistry pre-service and 32 mathematics pre-service teachers) and 64 in-service teachers ( 32 chemistry in-service and 32 mathematics in-service teachers). The study group was determined with convenience sampling method. Of the 64 pre-service teachers, 49 were female and 15 were male. In addition, of the 64 in-service teachers, 43 were female and 21 were male. Preservice and inservice teachers were participated voluntarily in the study.

\subsection{Data collection tool}

Teachers' Sense of Efficacy Scale (TSES) developed by Tschannen-Moran and Woolfolk Hoy [2], translated, and adapted into Turkish by Çapa, Çakıroğlu, and Sarıkaya [8] was used as data collection tool. The short version of the Teachers' Sense of Efficacy Scale (TSES) was used as a data collection tool. The scale was consisted of 12-items divided into three sub-scales, named as Efficacy for instructional Strategies (EIS), Efficacy for Classroom Management (ECM), and Efficacy for Student Engagement (ESE). Each item is scored on a 9-point Likert scale with $1=$ nothing and $9=$ a great deal. The Cronbach's alpha coefficient for internal consistency was .93 for the entire scale, .86 for the subscale EIS, .84 for the subscale ECM and .82 for the subscale ESE.

\subsection{Analyses of the data}

An independent-samples t-test was conducted to compare the sense of efficacy for preservice and in-service teachers.

\section{Findings}

The findings of independent-samples t-test were given in Table 1, 2 and 3.

According to Table 1, a statically significant difference was found in the ECM scores between preservice and in-service teachers in favor of in-service teachers $(t=-3.33$, $\mathrm{p}=.001$, two-tailed). However, when a comparison was made according to the discipline (for chemistry and mathematics), it was determined that there was no significant difference between the in-service and preservice chemistry and in-service and preservice mathematics teachers in terms of ECM scores. When a comparison was made for the gender, no significant difference was determined between mathematics and chemistry in-service and 
preservice teachers. There was no significant difference between chemistry and mathematics in-service and chemistry and mathematics preservice teachers. In addition, there was no significant difference between male and female in-service and male and female preservice teachers in ECM scores.

Table 1. Findings of independent-samples t-test for Efficacy for Classroom Management (ECM)

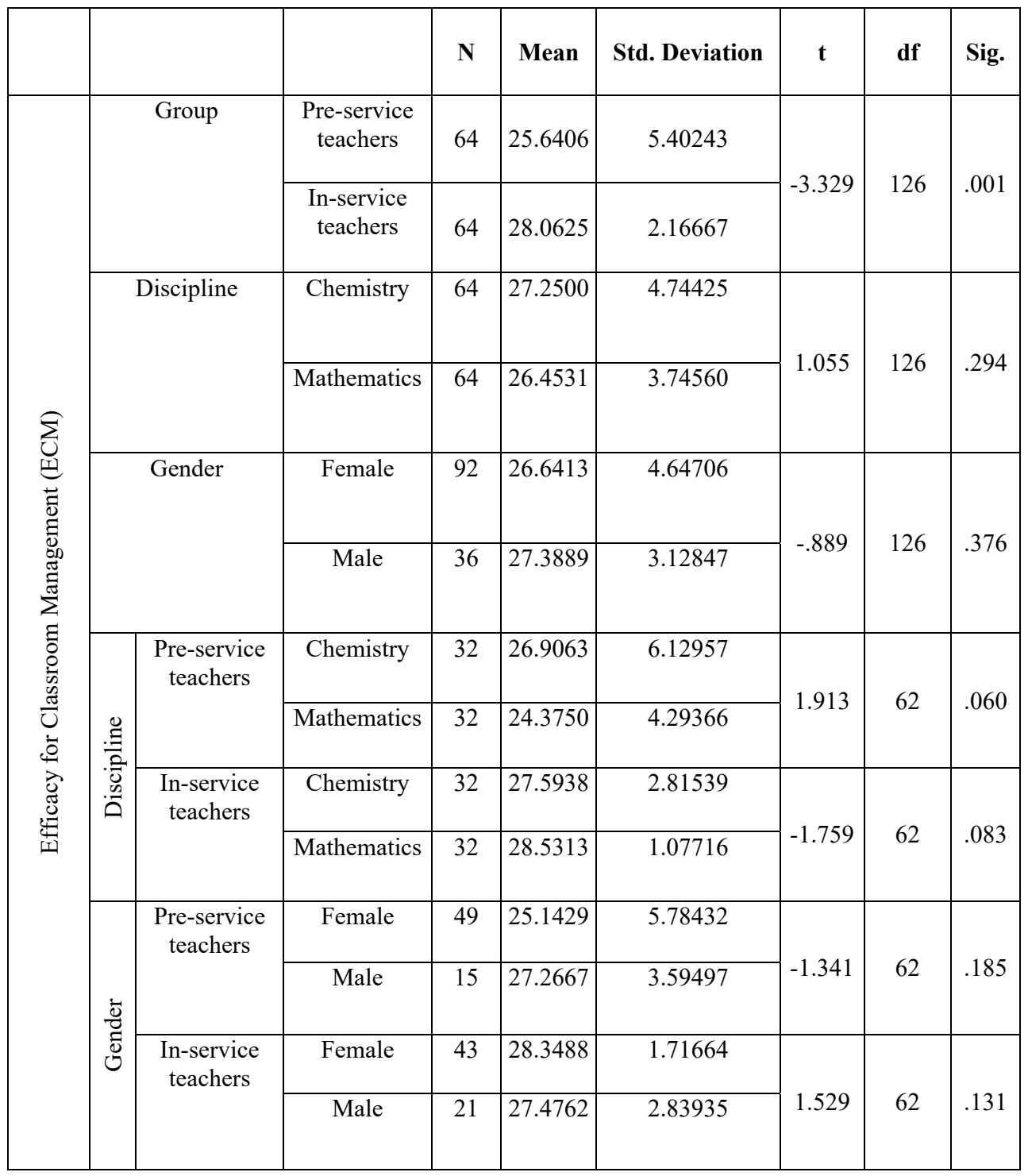

According to the independent sample $t$ test results in Table 2, it was determined that there was no significant difference between in-service and preservice teachers in terms of ESE scores. However, the results showed that there was a significant difference between inservice and preservice chemistry and in-service and preservice mathematics teachers in ESE scores. In addition, results of t-test revealed that there was no significant difference between male preservice and in-service teachers and female preservice and in-service teachers. When a comparison of chemistry and mathematics preservice teachers' ESE 
scores was made, it was determined that there was a significant difference in favour of the chemistry preservice teachers. In addition, when a comparison of chemistry and mathematics in-service teachers' ESE scores was made, it was determined that there was no a significant difference. While it was determined that there was no significant difference between the male and female preservice teacher in ESE scores, a significant difference between male and female in-service teachers in ESE scores was found in favor of male inservice teachers.

Table 2. Findings of independent-samples t-test for Efficacy for Student Engagement (ESE)

\begin{tabular}{|c|c|c|c|c|c|c|c|c|c|}
\hline & & & & $\mathbf{N}$ & Mean & Std. Deviation & $\mathbf{t}$ & df & Sig. \\
\hline \multirow{14}{*}{ 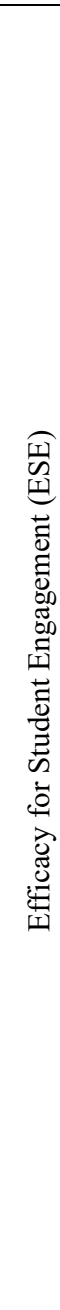 } & \multirow{2}{*}{\multicolumn{2}{|c|}{ Group }} & $\begin{array}{c}\text { Pre-service } \\
\text { teachers }\end{array}$ & 64 & 26.3750 & 4.79583 & \multirow[b]{2}{*}{-1.645} & \multirow[b]{2}{*}{126} & \multirow[b]{2}{*}{.102} \\
\hline & & & $\begin{array}{l}\text { In-service } \\
\text { teachers }\end{array}$ & 64 & 27.5625 & 3.21640 & & & \\
\hline & \multirow{2}{*}{\multicolumn{2}{|c|}{ Discipline }} & Chemistry & 64 & & & \multirow[b]{2}{*}{4.473} & \multirow[b]{2}{*}{126} & \multirow[b]{2}{*}{.000} \\
\hline & & & Mathematics & 64 & 25.4531 & 3.90738 & & & \\
\hline & \multirow{2}{*}{\multicolumn{2}{|c|}{ Gender }} & Female & & & 4.17819 & \multirow[b]{2}{*}{-1.791} & \multirow[b]{2}{*}{126} & \multirow[b]{2}{*}{.076} \\
\hline & & & Male & 36 & 28.0000 & 3.79473 & & & \\
\hline & \multirow{4}{*}{ 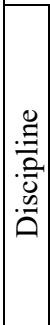 } & \multirow[t]{2}{*}{$\begin{array}{c}\text { Pre-service } \\
\text { teachers }\end{array}$} & Chemistry & 32 & 27.5938 & 4.72372 & \multirow{2}{*}{2.086} & \multirow{2}{*}{62} & \multirow{2}{*}{.04} \\
\hline & & & Mathematics & 32 & 25.1563 & 4.62189 & & & \\
\hline & & \multirow[t]{2}{*}{$\begin{array}{l}\text { In-service } \\
\text { teachers }\end{array}$} & Chemistry & 32 & 29.3750 & 2.18130 & \multirow{2}{*}{5.434} & \multirow{2}{*}{62} & \multirow{2}{*}{.000} \\
\hline & & & Mathematics & 32 & 25.7500 & 3.07959 & & & \\
\hline & \multirow{4}{*}{ 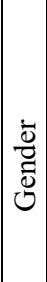 } & \multirow[t]{2}{*}{$\begin{array}{c}\text { Pre-service } \\
\text { teachers }\end{array}$} & Female & 49 & 26.5306 & 4.91639 & \multirow[b]{2}{*}{.466} & \multirow[b]{2}{*}{62} & \multirow[b]{2}{*}{.643} \\
\hline & & & Male & 15 & 25.8667 & 4.50185 & & & \\
\hline & & \multirow[t]{2}{*}{$\begin{array}{c}\text { In-service } \\
\text { teachers }\end{array}$} & Female & 43 & 26.6047 & 3.19329 & \multirow[b]{2}{*}{-3.745} & \multirow[b]{2}{*}{62} & \multirow[b]{2}{*}{.000} \\
\hline & & & Male & 21 & 29.5238 & 2.27198 & & & \\
\hline
\end{tabular}


Table 3. Findings of independent-samples t-test for Efficacy for Instructional Strategies (EIS)

\begin{tabular}{|c|c|c|c|c|c|c|c|c|c|}
\hline & & & & $\mathrm{N}$ & Mean & Std. Deviation & $\mathrm{t}$ & df & Sig. \\
\hline \multirow{14}{*}{ 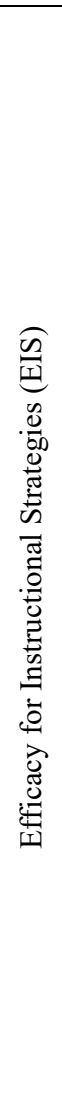 } & \multirow{2}{*}{\multicolumn{2}{|c|}{ Group }} & Pre-service & 64 & 26.5313 & 4.63927 & \multirow[b]{2}{*}{.706} & \multirow[b]{2}{*}{126} & \multirow[b]{2}{*}{.482} \\
\hline & & & $\begin{array}{l}\text { In-service } \\
\text { teachers }\end{array}$ & 64 & 26.0313 & 3.25610 & & & \\
\hline & \multirow{2}{*}{\multicolumn{2}{|c|}{ Discipline }} & Chemistry & 64 & 27.5313 & 4.63927 & \multirow[b]{2}{*}{3.709} & \multirow[b]{2}{*}{126} & \multirow[b]{2}{*}{.000} \\
\hline & & & Mathematics & 64 & 25.0313 & 3.25610 & & & \\
\hline & \multirow{2}{*}{\multicolumn{2}{|c|}{ Gender }} & Female & 92 & 25.7935 & 4.26470 & \multirow{2}{*}{-2.240} & \multirow{2}{*}{126} & \multirow{2}{*}{.027} \\
\hline & & & Male & 36 & 27.5278 & 2.92268 & & & \\
\hline & \multirow{4}{*}{ 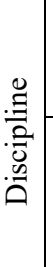 } & \multirow{2}{*}{$\begin{array}{c}\text { Pre-service } \\
\text { teachers }\end{array}$} & Chemistry & 32 & 26.9688 & 5.20226 & \multirow[b]{2}{*}{.752} & \multirow[b]{2}{*}{62} & \multirow[b]{2}{*}{.455} \\
\hline & & & Mathematics & 32 & 26.0938 & 4.03500 & & & \\
\hline & & \multirow{2}{*}{$\begin{array}{c}\text { In-service } \\
\text { teachers }\end{array}$} & Chemistry & 32 & 28.0938 & 2.05347 & \multirow[b]{2}{*}{6.531} & \multirow[b]{2}{*}{62} & \multirow[b]{2}{*}{.000} \\
\hline & & & Mathematics & 32 & 23.9688 & 2.92359 & & & \\
\hline & \multirow{4}{*}{$\begin{array}{l}\dot{\bar{v}} \\
\overline{0} \\
\dot{0}\end{array}$} & Pre-service & Female & 49 & 26.4082 & 4.87732 & \multirow[b]{2}{*}{-.381} & \multirow[b]{2}{*}{62} & \multirow[b]{2}{*}{.704} \\
\hline & & & Male & 15 & 26.9333 & 3.88158 & & & \\
\hline & & \multirow{2}{*}{$\begin{array}{c}\text { In-service } \\
\text { teachers }\end{array}$} & Female & 43 & 25.0930 & 3.35810 & \multirow[b]{2}{*}{-3.598} & \multirow[b]{2}{*}{62} & \multirow[b]{2}{*}{.001} \\
\hline & & & Male & 21 & 27.9524 & 1.98686 & & & \\
\hline
\end{tabular}

According to the results of the analysis for Efficacy for Instructional Strategies (EIS) scores, there was no significant difference between in-service and preservice teachers. When a comparison was made in EIS scores for the chemistry and mathematics discipline, there was a significant difference between in-service and preservice chemistry and mathematics teachers in favor of chemistry in-service and preservice teachers. In addition, when a comparison was made for gender, it was found that there was a significant difference in terms of EIS scores in favor of male in-service and preservice teachers. While it was determined that there was no significant difference between preservice chemistry and mathematics teachers in terms of EIS scores, but a significant difference was found between in-service chemistry and mathematics teachers in for favor of in-service chemistry teachers. In addition, while there was no significant difference between male and female preservice teachers in terms of EIS scores, a significant difference was found between female and male in-service teachers in favor of male in-service teachers. 


\section{Discussion and conclusions}

In the current research, the sense of efficacy for pre-service and in-service teachers was compared. According to the results of independent-samples t-test revealed that there was only a statistically significant difference in Efficacy for Classroom Management scores for pre-service $(\mathrm{M}=25.64, \mathrm{SD}=5.4)$ and in-service teachers $(\mathrm{M}=28.06, \mathrm{SD}=2.17 ; \mathrm{t}(126)=$ $-3.329, \mathrm{p}=.001$, two-tailed). This difference is not surprising. Because in a study by Cheung [9], it was stated that teachers' teaching experience had an effect on their selfefficacy. Birenbaum and Rosenau [10] found that in-service teachers' self-efficacy was higher than preservice teachers' self-efficacy. In another study by Campbell [11], it was revealed that in-service teachers' self-efficacy beliefs were higher than preservice teachers' self-efficacy beliefs. In a study conducted by Yaylı and İkizler [12], it was determined that in-service teachers' Efficacy for Classroom Management, Efficacy for Instructional Strategies and Efficacy for Student Engagement scores were higher than preservice teachers' scores. However, there was no significant difference in Efficacy for Instructional Strategies and Efficacy for Student Engagement scores for pre-service and in-service teachers. The reason why there is no significant difference in terms of these two variables can be in-service teachers' professional development, education and training. In a study conducted by Cheung [9], it was determined that the pre-service education of in-service teachers could be effective on their self-efficacy.

When a comparison is made for the disciplines (chemistry and mathematics) and gender, it was determined that there was no significant difference in Efficacy for Classroom Management scores. In addition, there was a statistically significant difference in Efficacy for Student Engagement scores for chemistry $(\mathrm{M}=28.48, \mathrm{SD}=3.76)$ and mathematics pre and in-service teachers $(\mathrm{M}=25.45, \mathrm{SD}=3.91 ; \mathrm{t}(126)=4.473, \mathrm{p}=.000$, two-tailed $)$. Nevertheless, there was no significant difference in Efficacy for Student Engagement scores for females and males. When examined the results obtained from the comparison of preservice and in-service teachers' Efficacy for instructional Strategies in terms of gender and discipline variables, it was determined that there was a statistically significant difference for chemistry $(\mathrm{M}=27.53, \mathrm{SD}=4.64)$ and mathematics pre and in-service teachers $(\mathrm{M}=25.031, \mathrm{SD}=3.26 ; \mathrm{t}(126)=3.71, \mathrm{p}=.000$, two-tailed $)$. In addition, there was a significant difference in Efficacy for instructional Strategies scores for females and males in favor of male preservice and in-service teachers. In the literature, it was reported that the sense of efficacy of male in-service teachers was higher than the female in-service teachers $[13,14]$. In a study conducted by Cheung [9], it was determined that female inservice teachers had a higher sense of efficacy than male in-service teachers. However, there are few studies in the literature where different results are obtained from the results of this study. For example, Aurah and McConnell [15] found that gender had no effect on the personal science-teaching efficacy of male and female science teachers.

Consequently, it was determined that there was a significant difference between inservice and preservice teachers' efficacy for Classroom Management scores. Qualitative studies could be conducted to reveal the reasons behind the emergence of this result. Thus, it is better to understand the factors that affect the sense of efficacy of in-service and preservice teachers.

\section{References}

1. A. Bandura, Self-efficacy: the exercise of control (New York: W, H, Freeman and Company 1997)

2. M. Tschannen-Moran, A. W. Hoy, Teach. Teach. Educ. 17, 783 (2001) 
3. D. H. Schunk, Educ. Psychol. 26, 207 (1991)

4. C. A. Wolters, S. G. Daugherty, J. Educ. Psychol. 99, 181 (2007)

5. E. M. Skaalvik, S. Skaalvik, Teach. Teach. Educ. 26, 1059 (2010)

6. R. M. Allinder, Teach. Educ. Spec. Educ. 17, 86 (1994)

7. S. Simbula, D. Guglielmi, W. B. Schaufeli, Eur. J. Work. Organ. Psy. 20, 285 (2011)

8. Y. Çapa, J. Çakıroğlu, H. Sarıkaya, Educ. Sci. 30, 74 (2005)

9. H. Y. Cheung, Aust. Educ. Res. 35, 103 (2008)

10. M. Birenbaum, S. Rosenau, J. Educ. Teach. 32, 213 (2006)

11. J. Campbell, Educ. 117, 2 (1996)

12. D. Yayl1, F. Ekizler, J. Lang. Educ. Res. 1, 44 (2015)

13. J. G. M. Imants, C. J. De Brabander, Teach. Teach. Educ. 12, 179 (1996)

14. R. Murshidi, M. M. Konting, H. Elias, F. S. Fooi, Teach. Educ. 17, 265 (2006)

15. C. M. Aurah, T. J. McConnell, Am. J. Educ. Res. 2, 233 (2014) 